\title{
Shipping Container as Shelter Provision Solution for Post-Disaster Reconstruction
}

\author{
Cher Siang Tan ${ }^{1 *}$, Philip C.H. Ling ${ }^{1}$ \\ ${ }^{1}$ Faculty of Civil Engineering, Universiti Teknologi Malaysia, 81310 Skudai, Johor, Malaysia
}

\begin{abstract}
The emerging of shipping container house can help to relief the challenging issue in provision of dwelling in certain countries with overpopulation or surge of refugee. However, the suitability of shipping container, which is initially designed for transportation purpose, for shelter usage is not well understand. This paper aims to understand the current research on the technical aspect of container for shelter provision and the gaps of knowledges. Literature review is done on the up-to-date research about the container shelter and the potential of container shelter is summarized. From the study, shipping container can be suitable for shelter provision with some improvement to be done.
\end{abstract}

\section{Introduction}

The influx of refugee from natural disaster or conflicts into developed countries together with overpopulation trend in developing countries had led toward more challenging housing supply. Current provision of temporary shelter had been associated with several issues and unable to cater the increasing demand from market. An alternative housing solution is essential to provide more comfortable accommodation to these people in shorter time with lower construction cost.

ISO shipping container, been standardized steel box to be purposed for universal cargo transportation, is one of the potential candidates to solve the housing problem. The shipping container is designed to withstand harsh weathering and heavy loading over long distance transportation. This makes it very durable and suitable for housing purpose. As the matter of fact, modified shipping container had been used in construction industry for decades and being popularized among architect and engineers in recent years [1-3].

Although the usage of container as building is not a whole new concept, its suitability for living purpose, especially used as shelter for displaced people is not thoroughly investigated. It is important to know the suitability container house for residential purpose from technical perspective as it is crucial prior to planning stage on whether the container shelter provision is feasible or not.

This paper aims to provide insight on the technical information of shipping container for shelter purpose. Literature review on researches related to container shelter is done to obtain the latest information on technical issue of container house and gap of knowledges.

\footnotetext{
* Corresponding author: tcsiang@utm.my
} 
The suggestion of works will be proposed to encourage further researches to be done for improvement of container house.

\section{ISO shipping container for shelter purpose}

\subsection{Buildability of container shelter based on design and material}

ISO shipping container is built to the specification stated by International Standard Organization (ISO) and International Convention for Safe Containers (CSC) [4]. It is constructed of $1.905 \mathrm{~mm}$ corrugated sheet steel as the wall and roof, and $4.572 \mathrm{~mm}$ tubular steel frame for the corner post. ISO shipping containers has standard height $\times$ width $=2.438$ $\mathrm{m} \times 2.438 \mathrm{~m}$, and two common lengths of $6.96 \mathrm{~m}$ (referred to " 20 - $\mathrm{ft}$ container") and 12.192 $\mathrm{m}$ (referred to "40-ft container"). Some special 40-ft container might have the height of $2.743 \mathrm{~m}(9-\mathrm{ft})$, which is called High Cube container. The standardization of container dimensions had ease the mobilization of container shelter as the lifting, transportation and connection of container can be done seamlessly with existing machinery. Modular construction is feasible by using container with fixed dimension as it allows uniform design and build approach and thus encourage mass production. Container shelter can also be preinstalled with necessary infrastructure such as cable and pipes, which favours for volumetric construction that further reduce the time of completion. However, the fixed container shape and size also restraint the design of architects and engineers. Limited inner space is not suitable for large family without any major renovation. The rectangular shape which had fixed width of $2.4 \mathrm{~m}$ is also challenging for designer to make partition. Lower height even without installation of celling will face difficulty in some countries as there is requirement from building code on minimum celling height. For instance, International Residential Code (IRC) allows ceiling height of 7 feet $(2.134 \mathrm{~m})$, which the container shelter able to achieve [5].

In term of availability and price of raw material, the global supply of shipping container is in surplus as there are huge amounts of shipping containers left in the ports every year. For instance, the are 125,000 TEUs left in London [6] in Year 2002; and from Year 2005 to Year 2012 there are averagely 43,000 TEUs container left in Port Klang, Malaysia [7]. Typical cost for a new container is USD4000 and ranged USD1000-USD2500 for a used container [6,8]. However, this price can skyrocket to USD5000-USD15000 after it is modified into non-emergency container house [6,9]. With mass production and redesign of container for much simpler disaster-relief purpose, container shelter is expected to have lower cost, but further investigation should be done on this matter.

Container shelter can also be a solution for sustainable construction. Compared to temporary shelter which consume many natural resources such as tree and bamboo, reuse of container as shelter can help to conserve the environment. Melting down 3.6 tonnes ( 8000 $\mathrm{lbs}$ ) container to make steel beam requires $8000 \mathrm{~kW}$-hrs of electrical energy, but to convert it into a container home would require $400 \mathrm{~kW}$-hrs energy, that saves $95 \%$ energy [10,11]. It shows that reusing shipping container for building architecture stand a chance to minimise carbon footprint and maximise affordable home solution at the same time. Besides, Vijayalaxmi made a comparison of embodies energy and indoor thermal performance of Greentainer to conventional brick building in hot-humid weather (tropical weather of India). It is found that the steel container building produced $32317.68 \mathrm{MJ}$ lesser than traditional brick building, and the indoor temperature was only $0.3^{\circ} \mathrm{C}$ difference [11]. 


\subsection{Structural performance of shipping container shelter}

The strength of the shipping container is specified in ISO specification. For a shipping container to obtain accreditation from ISO, it must pass the structural test which consists several loading criteria. A shipping container should be able to sustain $942 \mathrm{kN}$ of compressive force from top, $150 \mathrm{kN}$ of lateral force from longer side of container and $75 \mathrm{kN}$ of lateral force from shorter side of container for every corner fitting, with sway-deflection should be less than $5 \mathrm{~mm}$ for lateral loading, which is shown in Figure 1[12]. These structural strength makes the shipping container a suitable material for housing purpose as the inherit strength enable the stacking of container to form multi-storey building. This is a great advantage as high strength combined with uniform dimension of shipping container will favour the modular construction, which will reduce the completion time and thus overall construction cost.

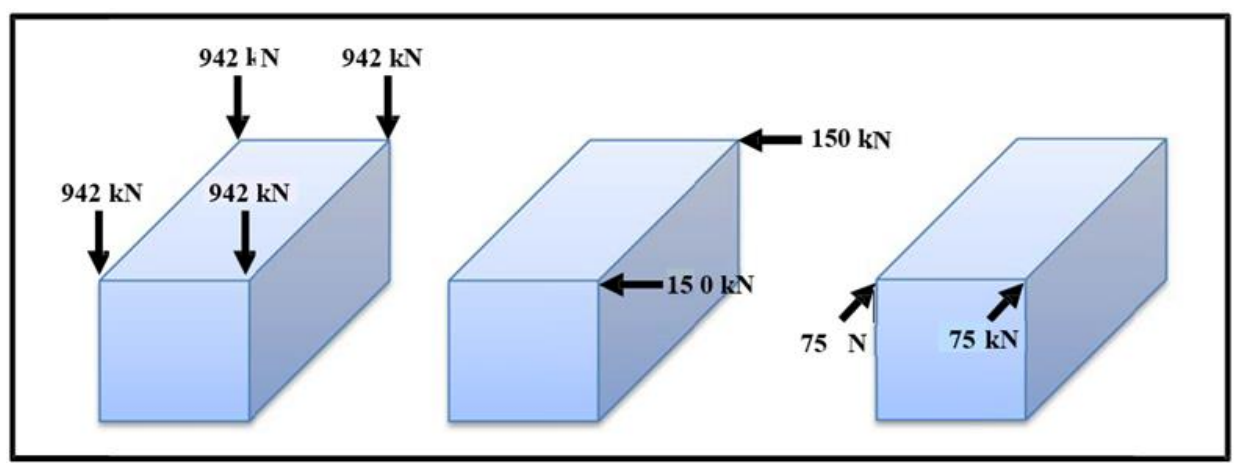

Fig.1. Examples of standard load tests on ISO shipping container

However, for residential intention, a shipping container must be modified by cutting out the wall panel to form windows and door for ventilation and other service piping. These opening will eventually affect the structural performance of shipping container and thus its strength will be lower than what had been specified in standard. On the other hand, second hand shipping container is usually used in construction for its lower cost and more environmental friendly. However, the shipping container will have defect during the lifting, loading or transportation process. The uses of CORTEN steel for container makes it durable and resistant to weathering as it will form a protective oxide layer at the surface of virgin steel to prevent further rusting. However, the weathering of the steel material for shipping container will affect the durability of the container house in long run. Hence, it is important to do inspection and evaluation on defect prior to using it in construction. Giriunas had summarized some damage check list of containers suggested by US Department of Defense in his master thesis [13].

There are several researches been conducted to investigate the structural performance of shipping container house using different approach. Dated to 1987, a group of researchers had created a space frame model to stimulate the shipping container under ISO loading requirement [14]. Although the results did not represent the actual behavior of container structure especially on wall panel, this approach of numerical analysis had been adopted in future researches as computer-aid analysis can process numerous types of container house configuration, in which the full-scale experiment cannot be done frequently.

In 2007 and 2008, two groups of researchers from Norway and United States had separately reported on the testing of container house under blast loading $[15,16]$. Both groups had modified the wall panel of container by incorporating it with another steel panel and infill the space with polystyrene or with aluminium panel infilled with gravel. Both 
researches aimed to develop a suitable container shelter for military purpose and thus the testing done involved blasting, which is seldom encountered in usual residential purpose.

Two doctorate candidates at Japan had conducted the research on the container stack dynamics [17] in Year 2009. They had fabricated the scaled-down model for the container and tested it under $2 \times 1,7 \times 1$, and $7 \times 3$ stacking configuration using shacking table for their dynamic behaviour. The results were then validated by finite element analysis. These are the only few literatures that depict the stacking behaviour of container, which is crucial for container housing industry as it is a norm to stack the container house for more efficient space utilization.

A Master student from United States had analysed the shipping container using finite element analysis [18]. By using commercial available software, numerical models of shipping container with different configuration of total wall removal were developed and tested under the loading specified as ISO requirement. From the results of study, the removal of wall will result in lower stiffness of container and the resistance of container toward lateral loading will be greatly affected if the wall panel along the loading direction is removed. In real world scenario however, the total wall removal is often avoided but this research did give conservative result for reference.

In 2016, two researchers from China had developed the theoretical stiffness of a container with and without opening on wall panel $[19,20]$. By using diaphragm theory, they had developed the formulation for the stiffness of corrugated wall on container. Together with the verification from finite element analysis and full-scale experiment, it showed good agreement among three approaches. To date, these are the only literature on the theoretical study of container stiffness.

\subsection{ISO shipping container as shelter for Post-Disaster Reconstruction (PDR)}

Unlike other refugee shelters, the use of ISO shipping container for PDR has the unique advantage of multi-storey constructability. This advantage is inevitable when the land area for refugee camp is limited, in the case of sub-urban zones. Take example of a land size of a football field, it can accommodate maximum 181 units of Ikea Refugee Shelter to house 905 refugees. With container shelter, 324 units of dwellings can be constructed in a threestorey flat arrangement to house 1296 refugees, and at the same time offer a free land area of $4250 \mathrm{~m} 2$ for common and re-habitation activities. The 3-storey container flats have the possibility to be expanded vertically (into 4-5 storey) to house more people with proper urban design and engineering consideration considered.

The use of second hand containers for PDR design reuses existing steel material, instead of manufacturing new construction materials (e.g. polypropylene tents) for PDR. This advantage is more significant when large number of containers are used to transport the food and medical supplies to the disaster zones, or there are existing container storages (e.g. ports, jetty and railway station) near to the disaster area. The container shelter could be rapidly installed as core-dwelling for the refugee, and later being renovated into permanent houses. On the other hand, if the container shelters are left unoccupied after the refuges have restored their lives in other habitants, the steel material of containers can be recycled, or relocated to other places for other usage, e.g. temporary school classes, market bazar, storeroom etc.

Rabenatoandro [21] has made some case studies on three-storey container shelter under flood water and wind loads, and the results showed that the container shelter is resistible to these natural impacts. The preliminary findings show that multi-storey container core dwelling is constructible; anyway, further analysis and validation are needed on the resistances of container core-dwelling. Regards to foundation design, different types of 
foundation e.g. steel piles, concrete pad footing, strip footing etc. are applicable for container core dwelling. The design of foundation is strongly affected by the location conditions of the refugee camp (types of soil, water level, seismic activity etc), and the building design life, e.g. concrete pad footing is suitable for permanent house development in future; wood or steel piles would be sufficient for temporary building, and they are easily removable or recyclable when the refugee camp is dismantled. Anchoring foundation should be designed if the shelters are subjected to flood and strong wind impact which are common in hydro-meteological disaster area. Some research works on the suitability of using ISO shipping container for low cost house and disaster shelter provision have been carried out in Malaysia [22-24]. The works included survey on the acceptability of local residents towards container houses [22], feasibility analysis [23], workshop discussion, field visit to disaster area and laboratory test on container with openings [24]. The findings indicated that more works need to be done for the adaptability of steel core-housing in a tropical climate country, especially in construction detailing, cost and structural reliability.

The reuse of second hand ISO shipping container has the hidden risk of the quality of the procured containers. Severe rusts, parts damages, and distortion of container could make the PDR design more difficult or become impossible. Thus, standard of procedures (SOP) to check and validate the quality of used container before PDR begins is important. The SOP can be referred to the recommendations by CSC guides, ISO668-1995 and US Department of Defence. For example, the dimension and diagonal tolerances of a used container should be fall within the values given by ISO668-1995 to ensure the container remain its structural integrity. Better and simpler SOP with layman terms could be developed for the ease of use by aid organizations and local people at disaster zones.

Shelter Centre has developed standard requirements for the manufacturing of shelters [25]. The checklist on container core-dwelling is made by Robenatoandro [21]. From the checklist prepared, it is found out that the container core dwelling fulfilled most of the Shelter Centre requirements, which regards to its buildability, usable area, ventilation, colour and environmental toxicity. However, the container core dwelling does not meet the "weight and package" requirements due to its huge size and heavy self-weight compared to normal shelters. In term of fire safety, container shelter fulfilled partial requirements because steel is not a flammable material, but further improvements are needed to enhance its resistance against fire incidents, especially for habitant usage. The checklist result is depicted in Table 1 and Figure 2.

Table 1. Shelter Centre Requirements Check List for Container Shelter [21,25]

\begin{tabular}{|c|l|l|c|}
\hline No & \multicolumn{1}{|c|}{$\begin{array}{c}\text { Standard } \\
\text { Requirements }\end{array}$} & \multicolumn{1}{|c|}{$\begin{array}{c}\text { Standard } \\
\text { Fulfillment }\end{array}$} & $\begin{array}{c}\text { Standard Met? } \\
\text { (Yes/No) }\end{array}$ \\
\hline 1 & $\begin{array}{l}\text { Complete package has a mass } \\
\text { between 40kg and 80kg. }\end{array}$ & $\begin{array}{l}\text { Empty container weight } \\
300 \mathrm{~kg} \text {. Fully loaded } \\
\text { container can reach 3000 } \\
\text { kg. }\end{array}$ & $\mathrm{N}$ \\
\hline 2 & $\begin{array}{l}\text { Total shelter is in one package } \\
\text { which can be broken down to } \\
\text { smaller packages, suitable for } \\
\text { transport for 2 people. }\end{array}$ & $\begin{array}{l}\text { Container is provided in } \\
\text { standard and fixed size. It } \\
\text { is transportable by forklift } \\
\text { or mobile crane. }\end{array}$ & $\mathrm{N}$ \\
\hline
\end{tabular}




\begin{tabular}{|c|c|c|c|}
\hline 3 & $\begin{array}{l}\text { Complete shelter has } \\
\text { packed volume between } \\
0.3 \mathrm{~m}^{3} \text { and } 0.5 \mathrm{~m}^{3} \text {. }\end{array}$ & $\begin{array}{l}20 \text { - } \mathrm{ft} \text { container standard } \\
\text { volume is } 37.5 \mathrm{~m}^{3}\end{array}$ & $\mathrm{~N}$ \\
\hline 4 & $\begin{array}{l}\text { Longest dimension of } \\
\text { packed shelter is no more } \\
\text { than } 200 \mathrm{~cm} .\end{array}$ & $\begin{array}{l}\text { Longest dimension of } \\
\text { Container is } 6 \mathrm{~m}(20-\mathrm{Ft})\end{array}$ & $\mathrm{N}$ \\
\hline 5 & $\begin{array}{l}\text { At least } 4 \text { packed shelters can } \\
\text { fit onto a } 120 \times 80 \mathrm{~cm} \text { Euro } \\
\text { pallet. }\end{array}$ & $\begin{array}{l}\text { Pallet can be fitted into } \\
\text { container, but not the other } \\
\text { way round. }\end{array}$ & $\mathrm{N}$ \\
\hline \multirow[t]{2}{*}{6} & $\begin{array}{l}\text { The packed shelters can be } \\
\text { packed vertically onto a } \\
120 \mathrm{x} 80 \mathrm{~cm} \text { Euro pallet. }\end{array}$ & $\begin{array}{l}\text { Pallet can be fitted into } \\
\text { container, but not the other } \\
\text { way round. }\end{array}$ & $\mathrm{N}$ \\
\hline & Useable area & & \\
\hline 27 & $\begin{array}{l}\text { The shelter should be of } \\
\text { sufficient size to house a family } \\
\text { of } 5 \text {, with between } 3.5 \mathrm{~m}^{2} \text { and } \\
4.5 \mathrm{~m}^{2} \text { of covered living area. }\end{array}$ & $\begin{array}{l}20 \text {-ft container provides } \\
\text { covered area of } 15 \mathrm{~m}^{2} \text {, and } \\
\text { could be extended with } \\
\text { modular construction. No } \\
\text { problem to house } 4-5 \\
\text { people. }\end{array}$ & $\mathrm{Y}$ \\
\hline 28 & $\begin{array}{l}\text { The standing height of the } \\
\text { covered space is a minimum } \\
\text { of } 180 \mathrm{~cm} \text { over at least } 60 \% \\
\text { of the covered floor area. }\end{array}$ & $\begin{array}{l}\text { Height } 250 \mathrm{~cm} \text { for whole } \\
15 \mathrm{~m}^{2} \\
\text { area. }\end{array}$ & Y \\
\hline 32 & $\begin{array}{l}\text { The inner liner has integrated } \\
\text { storage pockets. }\end{array}$ & $\begin{array}{l}\text { Storage racks, furniture can } \\
\text { be installed }\end{array}$ & Y \\
\hline \multirow[t]{2}{*}{33} & $\begin{array}{l}\text { There are no guy ropes or other trip } \\
\text { hazards around the shelter. }\end{array}$ & $\begin{array}{l}\text { No guy ropes in container } \\
\text { house }\end{array}$ & Y \\
\hline & Ventilation & & \\
\hline 34 & $\begin{array}{l}\text { Minimum ventilation shall be } \\
\text { achieved through an } \\
\text { unobstructed aperture with a } \\
\text { total area equivalent to } 0.01 \mathrm{~m}^{2} \text {. }\end{array}$ & $\begin{array}{l}\text { Ventilation hole can be } \\
\text { drilled. To future specified } \\
\text { detailing. }\end{array}$ & Y \\
\hline 37 & $\begin{array}{l}\text { All doors and openings are } \\
\text { adjustable to control light and } \\
\text { heat gain or loss. }\end{array}$ & $\begin{array}{l}\text { Doors and openings can } \\
\text { be cut from the wall of } \\
\text { container. To future } \\
\text { specified detailing. }\end{array}$ & $\mathrm{Y}$ \\
\hline & Fire Safety & & \\
\hline
\end{tabular}




\begin{tabular}{|c|c|c|c|}
\hline 42 & $\begin{array}{l}\text { The shelter has two opposite } \\
\text { doors to facilitate escape in } \\
\text { case of fire. }\end{array}$ & $\begin{array}{l}\text { Doors and openings can } \\
\text { be cut from the wall of } \\
\text { container. To future } \\
\text { specified detailing. }\end{array}$ & $\mathrm{Y}$ \\
\hline \multirow[t]{2}{*}{43} & $\begin{array}{l}\text { It is possible to exit the shelter } \\
\text { within } 30 \text { seconds when all } \\
\text { doors are fully closed. }\end{array}$ & $\begin{array}{l}\text { Doors and openings can } \\
\text { be cut from the wall of } \\
\text { container. To future } \\
\text { specified detailing. } \\
\text { Special note has to be } \\
\text { taken that steel can be } \\
\text { heated up very fast and at } \\
\text { very high temperature. }\end{array}$ & $\mathrm{Y}$ and $\mathrm{N}$ \\
\hline & Vector Control & & \\
\hline \multirow[t]{2}{*}{46} & $\begin{array}{l}\text { The shelter has a } 10 \mathrm{~cm} \text { vertical } \\
\text { edge around the base of entry } \\
\text { points to impede the entry of } \\
\text { insects. }\end{array}$ & $\begin{array}{l}\text { Container is ideally } \\
\text { installed } 60 \mathrm{~cm} \text { above } \\
\text { ground level, supported by } \\
\text { concrete or rock pillar. To } \\
\text { future specified detailing. }\end{array}$ & $\mathrm{Y}$ \\
\hline & Environmental Toxicity & & \\
\hline 49 & $\begin{array}{l}\text { The shelter does not involve } \\
\text { materials that are toxic to } \\
\text { humans, even when cut or } \\
\text { modified for later re-use. }\end{array}$ & $\begin{array}{l}\text { Containers are mainly steel } \\
\text { product which does not } \\
\text { harm environment. Further } \\
\text { modular renovation } \\
\text { materials are to future } \\
\text { specified detailing. }\end{array}$ & $\mathrm{Y}$ \\
\hline \multirow[t]{2}{*}{51} & $\begin{array}{l}\text { The shelter does not involve } \\
\text { materials that are toxic by } \\
\text { burning or burying, and shall not } \\
\text { pollute the ground water table or } \\
\text { enter the food chain. }\end{array}$ & $\begin{array}{l}\text { Steel cannot be burnt. It is } \\
\text { reusable, and can be } 100 \% \\
\text { recycled during disposal } \\
\text { stage. }\end{array}$ & $\mathrm{Y}$ \\
\hline & Color & & \\
\hline 52 & $\begin{array}{l}\text { Military or camouflage colors are } \\
\text { not to be used. }\end{array}$ & $\begin{array}{l}\text { Container can be painted in } \\
\text { white }\end{array}$ & $\mathrm{Y}$ \\
\hline \multirow[t]{2}{*}{58} & $\begin{array}{l}\text { The shelter can be distributed as a } \\
\text { complete package, ready to put } \\
\text { up, with all components included } \\
\text { and all required tools. }\end{array}$ & $\begin{array}{l}\text { Yes. Container itself is a } \\
\text { complete frame, and all } \\
\text { renovation tools and } \\
\text { materials can be packed } \\
\text { inside. }\end{array}$ & $\mathrm{Y}$ \\
\hline & Buildability & & \\
\hline
\end{tabular}




\begin{tabular}{|l|l|l|l|}
\hline 63 & $\begin{array}{l}\text { The frame is strong enough to } \\
\text { support } 6 \text { to } 830 \mathrm{~kg} \text { hanging live } \\
\text { loads. }\end{array}$ & $\begin{array}{l}\text { Container floor is designed } \\
\text { to support } 300 \mathrm{kN}(3000 \\
\mathrm{kg}) \text { loads. The roof must be } \\
\text { designed to future specified } \\
\text { detailing. }\end{array}$ & $\mathrm{Y}$ \\
\hline
\end{tabular}

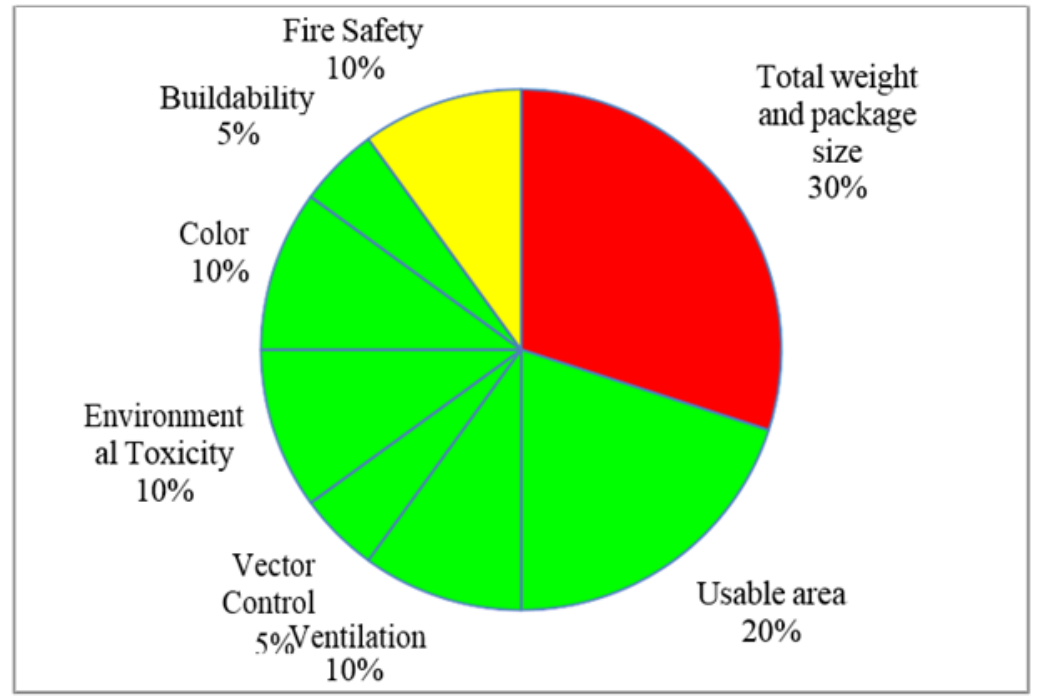

Fig. 1. Fulfilment of container core dwelling to Shelter Centre Checklists [21,25]

\section{Conclusions}

The deployment of shipping container as residential house can help to relief the shortcoming of suitable shelter for increasing population in some countries. From the results of review done, container shelter can be suitable with provision of fire safety and reduction of total weight and size. More research on shipping container for shelter purpose should be done to fully utilize its potential and improve its shortcoming.

The reported works is a collaborative research between Universiti Teknologi Malaysia (UTM) and Swiss Federal Institution of Technology Lausanne (EPFL) Switzerland. The authors would like to acknowledge the contribution by Professor Alain Nussbaumer of EPFL Switzerland. The authors also express their appreciation for the financial support from Malaysia Ministry of Higher Education (FRGS-4F834) and Universiti Teknologi Malaysia (GUP 13H37 \& 03G55).

\section{References}

1. Spillmann Echsle (2013). http://www.spillmannechsle.ch/seiten/ffsz.htm

2. Container City (2013). www.containercity.com

3. Wallace V. (2013). http://www.containerhome.info

4. BSI. BS ISO 668:1995. Series 1 freight containers - Classification, dimensions and ratings. British Standard Institutions. (2006).

5. International Code Consortium. International Residential Code. (2009) https://archive.org/download/gov.law.icc.irc.2009/icc.irc.2009.pdf 
6. Smith J.D. Shipping containers as building components. MSc Thesis. University of Brighton. (2006)

7. Port Klang Statistic

http://www.pka.gov.my/index.php/en/component/content/article/44-about-us/127port-klang-statistics.html

8. Sawyers P. Intermodal Shipping Containers for use as Steel Buildings. US: Library of Congress. (2005)

9. Shipping Container Home (2008) http://www.containerhomes.net/articles-andresearch/the- shipping-containers-homes-is-a-small-carbon-footprint-costarica.html

10. Shipping Container Home (2008) http://www.containerhomes.net/articles-andresearch/the- shipping-containers-homes-is-a-small-carbon-footprint-costarica.html

11. Vijayalaxmi J. Towards sustainable architecture - a case with Greentainer. Local Environment: The International Journal of Justice and Sustainability, 15:3 (2010) 245- 259.(2010)

12. BSI. BS 3951-2.1:1991+A5:2006 ISO 1496-1:1990+A5:2006. Freight containers - Part 2:Specification and testing of series 1 freight containers - Section 2.1 General cargo containers for general purposes. British Standard Institutions. (2010)

13. Giriunas K.A. Evaluation, modeling, and analysis of shipping container building structures. MSc Thesis. The Ohio State University. (2012)

14. Sinha, S. C., Prakash, V., Ravikumar, P. B., \& Raman, R.. Modeling and simulation of cargo containers. Computers \& Structures, 33(4), 1065-1072. (1989) https://doi.org/10.1016/0045-7949(89)90442-2

15. Børvik, T., Burbach, A., Langberg, H., \& Langseth, M.. On the ballistic and blast load response of a $20 \mathrm{ft}$ ISO container protected with aluminium panels filled with a local mass - Phase II: Validation of protective system. Engineering Structures, 30(6), 1621-1631. (2008) http://dx.doi.org/10.1016/j.engstruct.2007.10.011

16. Genelin, C. L., Dinan, R. J., Hoeman, J. M., \& Salim, H. A.. Evaluation of Blast Resistant Rigid Walled Expeditionary Structures. 13th International Symposium on the Interactions of the Effects of Munitions with Structures, Bruhel, Germany. (2009)

bin/GetTRDoc? Location $=$ U2\&doc $=$ GetTRDoc.pdf\&AD $=$ ADA500060

17. Aguiar de Souza, V., Kirkayak, L., Watanabe, I., Suzuki, K., Ando, H., Sueoka, H., \& Darama, H.. Experimental and numerical analysis of container multiple stacks dynamics using a scaled model. Ocean Engineering, 74, 218-232. (2013) http://dx.doi.org/10.1016/j.oceaneng.2013.05.013

18. Giriunas, K., Sezen, H., \& Dupaix, R. B.. Evaluation, modeling, and analysis of shipping container building structures. Engineering Structures, 43, 48-57. (2012) http://dx.doi.org/10.1016/j.engstruct.2012.05.001

19. Zha, X., \& Zuo, Y.. Theoretical and experimental studies on in-plane stiffness of integrated container structure. Advances in Mechanical Engineering, 8(3). (2016) doi:10.1177/1687814016637522

20. Zha, X., \& Zuo, Y.. Theoretical and experimental studies on in-plane stiffness of container structure with holes. Advances in Mechanical Engineering, 8(6), 1687814016651372. (2016) doi:10.1177/1687814016651372

21. Rabenatoandro E. Le container comme noyau de maisons résistant aux catastrophes naturelles. Projet de Master. Switzerland: EPFL. (2014) 
22. Edric King Hui Wong, Cher Siang Tan, Philip Chie Hui Ling. Feasibility of Using ISO Shipping Container to Build Low Cost House in Malaysia. International Journal of Engineering \& Technology. 7 (2.29) 933-939. (2018).

23. Cher Siang Tan, Alain Nussbaumer, Philip Chie Hui Ling. Container Shelter for Post-Disaster Reconstruction. International Conference on Durability of Building and Infrastructures (DuraBI2018). Jan 10-12 2018 Sarawak, Malaysia. (2018).

24. Cher Siang Tan \& Alain Nussbaumer. Structural Feasibility of ISO Shipping Containers for Core-dwelling Housing. IABSE Conference - Engineering the Developing World. April 25-27 2018, Kuala Lumpur, Malaysia. (2018).

25. Shelter Centre. Transitional Shelter Standard (Draft). Switzerland: Shelter Centre. 2010. 